\title{
Plants that cause photosensitivity in ruminants in Brazil
}

\section{Plantas que causam fotossensibilização em ruminantes no Brasil}

\author{
Sheila Nogueira Ribeiro Knupp ${ }^{1 *}$; Leonardo Sidney Knupp²; \\ Franklin Riet-Correa ${ }^{3}$; Ricardo Barbosa Lucena ${ }^{4}$
}

\begin{abstract}
This study aimed to review the mechanisms of action, clinical signs, pathology, and toxic compounds of plants that cause photosensitivity in ruminants. In addition, we sought to clarify the diagnostic methods and prophylaxis of photosensitivity-induced plants. Photosensitizing plants constitute an important group of poisonous plants in Brazil and there are at least seventeen species distributed in nine genera. Some of these plants have well known toxic compounds; in others, the substance responsible for the disease is unknown. In general, the photosensitivity can be classified as primary or secondary. Among the plants causing primary photosensitivity in Brazil, Ammi majus contains furocoumarins, while the compound in Froelichia humboldtiana remains uncertain. The known toxic compounds causing secondary photosensitivity include pyrrolizidine alkaloids, furans sesquiterpenes, triterpenes, and steroidal saponins. In other plants causing secondary photosensitization, including Stryphnodendron spp. and Enterolobium spp., the toxic compound is still unknown. Future research should be conducted in order to determine the various mechanisms of action of each toxic compound to assist the diagnosis of photosensitivity, to develop less toxic or non-toxic cultivars, or even to find new ways of preventing photosensitization.
\end{abstract}

Key words: Cow. Goat. Sheep. Intoxication. Poisonous plants.

\section{Resumo}

O presente trabalho teve como objetivo revisar os mecanismos de ação, os sinais clínicos, a patologia e os princípios tóxicos das plantas que causam fotossensibilização em ruminantes. Além disso, buscou-se esclarecer, de maneira sucinta e objetiva, os métodos diagnósticos e a profilaxia da fotossensibilização induzida por plantas. Plantas fotossensibilizantes em ruminantes constituem um grupo importante de plantas tóxicas no Brasil, existindo pelo menos 17 espécies de plantas fotossensibilizantes distribuídas em nove gêneros. Algumas delas têm princípio ativo conhecido; em outras não se conhecem as substâncias responsáveis pela doença. Em geral, a fotossensibilização pode ser classificada como primária e secundária. Das plantas descritas como fotossensibilizantes primárias no Brasil, apenas a Ammi majus teve seu princípio tóxico identificado (furocumarinas), enquanto o da Froelichia humboldtiana continua incerto. Outros princípios ativos fotossensibilizantes também foram descritos em plantas, porém causando fotossensibilização secundária, dentre eles estão os alcalóides pirrolizidínicos, os furanossesquiterpenos, os triterpenos, e as saponinas esteroidais. Existem ainda plantas reconhecidamente fotossensibilizantes secundárias que não apresentam princípio tóxico conhecido, como as do gênero Striphnodendron e

\footnotetext{
${ }^{1}$ Discente do Programa de Doutorado em Medicina Veterinária, Universidade Federal de Campina Grande, UFCG, Patos, PB, Brasil. E-mail: sheilanribeiro@hotmail.com

2 Discente do Programa de Doutorado Integrado em Zootecnia, Universidade Federal da Paraíba, UFPB, Areia, PB, Brasil. E-mail: leonardoknupp@hotmail.com

${ }^{3}$ Prof. Dr., Universidade Federal de Campina Grande, Unidade Acadêmica de Medicina Veterinária, UFCG-CSTR, Patos, PB. E-mail: franklin.riet@pq.cnpq.br

${ }^{4}$ Prof. Dr., Universidade Federal da Paraíba, Centro de Ciências Agrárrias, CCA-UFPB, Areia, PB. E-mail: lucena.rb@gmail.com

* Author for correspondence
} 
Enterolobium. Futuras pesquisas devem ser conduzidas com o objetivo de determinar os diversos mecanismos de ação de cada composto tóxico com vistas a auxiliar o diagnóstico da fotossensibilização, além de possibilitar o desenvolvimento de cultivares não sintetizantes desses compostos, ou ainda, novas formas de prevenção das fotossensibilizações.

Palavras-chave: Bovinos. Caprinos. Ovinos. Intoxicação. Plantas tóxicas.

\section{Introduction}

Photosensitization is a biophysical phenomenon that occurs when the skin becomes sensitive to certain wavelengths of sunlight in the presence of specific intraepithelial photodynamic agents (ANDREWS et al., 2004), resulting in dermatitis, anorexia, weight loss, and eventually death of the affected animals. This disease has been diagnosed for many years in different species of animals and causes problems in herds around the world (OLIVEIRA et al., 2013).

In Brazil, there are at least seventeen species of photosensitizing plants distributed in nine genera. The toxic compounds of some of these plants are well known, but in others remain unknown. This study aims to review the mechanisms of action, clinical signs, pathology, and toxic compounds of plants that cause photosensitivity in ruminants. The diagnostic methods and prophylaxis of photosensitivity induced by plants are also reviewed.

\section{Photosensitivity}

There are three forms of photosensitivity: primary (type 1), congenital (type 2), and hepatogenous or secondary (type 3 ). In type 1 , photosensitization is the primary manifestation, which arises due to the ingestion of exogenous substances with photodynamic action (HAARGIS; GINN, 2007; RADOSTITS et al., 2007). Congenital photosensitivity (type 2), which is rare in domestic animals, is associated with abnormal metabolism of porphyrins with aberrant synthesis of pigments. Photosensitivity type 3, or secondary, occurs when the liver's ability to excrete phylloerythrin, a pigment derived from chlorophyll degradation in the digestive tract, is impaired (HAARGIS; GINN, 2007).
In Brazil, there are two plants that cause primary photosensitization: Ammi majus (MÉNDEZ et al., 1991), which contain furocoumarins as their photosensitizing compounds (CHEEKE, 1998) and Froelichia humboldtiana (PIMENTEL et al., 2007, KNUPP et al., 2014; MEDEIROS et al., 2014) whose toxic compound is unknown. In other countries, primary photosensitization may be caused by Fagopyrum esculentum that contains a quinone conjugate, derived from naphthodianthrone called fagopyrin, and Hypericum perforatum that contains a substance similar to fagopyrin called hypericin (CHEEKE, 1998). The difference between the poisonings by furocoumarins and naphthodianthrones is that furocoumarins cause eye injuries, which are not observed in naphthodianthrone poisoning (YAGER; SCOTT, 1993).

Primary photosensitization caused by $F$. humboldtiana in sheep and cattle have been reported in the semiarid region of Brazil (PIMENTEL et al., 2007; SOUZA et al., 2012). The disease occurs at the end of the rainy season in pastures highly invaded by $F$. humboldtiana. Animals usually recover after their removal from areas invaded by this plant (PIMENTEL et al., 2007).

Outbreaks of hepatogenous photosensitivity (secondary) are frequently diagnosed in cattle and sheep, and cause significant economic losses, not only due to the risk of death, but also due to reduced productivity (PESSOA et al., 2013). In Brazil, the main plants that cause secondary photosensitivity are those containing pyrrolizidine alkaloids (e.g., Senecio spp.), furans sesquiterpenes (e.g., Myoporum spp.), triterpenes (e.g., Lantana spp.), and steroidal saponins (e.g., Brachiaria spp.). There are some plant species in which the toxic compound is unknown, including Stryphnodendron spp. and Enterolobium spp. (FERREIRA et al., 2009). 
Toxic compounds of plants thatcause photosensitivity

Furocoumarins (FC) The tricyclic components, FC, are formed by the linear (psoralen) or angled (isopsoralen) fusion of a furan ring with a coumarin (1,2-benzopyrone) and represent an important class of photoactive compound. In the presence of long ultraviolet light (UVA $\sim 365 \mathrm{~nm}$ ), the FC promote various biological effects due to their reactivity with DNA, other cellular components, and macromolecules (KITAMURA et al., 2005). Some adverse effects have been described because of the use of psoralen for the clinical treatment of certain human skin diseases; among these are erythema, rash, dermatitis, and skin tumors (MALEKI et al., 2014). There are also reports of outbreaks of photosensitivity caused by the ingestion of $A$. majus in cattle (MÉNDEZ et al., 1991) and poultry (EGYED et al., 1976). This plant contains several FC compounds found in higher concentrations in their seeds and fruits (ABU-MUSTAFA et al., 1975). The isolated photosensitizing $\mathrm{FC}$ from A. majus fruits and seeds are bergapten (5-methoxypsoralen), imperatorin, xanthotoxin (8-methoxypsoralen), marmesin, isopimpinellin, and amyrin (SUBRAMANIAN et al., 1996). Animals intoxicated with FC present dermatitis and keratoconjunctivitis with eyelid edema and eye congestion. After the removal of affected animals from direct contact with sunlight, the clinical signs tend to regress (MÉNDEZ et al., 1991).

Pyrrolizidine alkaloids (PA) These alkaloids do not show direct toxicity, but become toxic when biotransformed in the liver (CHEEKE, 1998). PA cause irreversible damage to the liver and some injure the lungs, such as monocrotaline, or the kidneys (SANTOS et al., 2008). PA are found in plants of the genus Senecio, Crotalaria, Erechtites, Heliotropium, Echium, Trichodesma, Cynoglossum, and Amsinckia (TOKARNIA et al., 2012). After ingestion, these plants cause progressive and irreversible damage to hepatocytes due to mitotic inhibition. In the terminal stages, the hepatocytes do not metabolize urea culminating with hyperammonemia and death of the animal
(STALKER; HAYES, 2007). Clinical signs are characteristic of hepatic encephalopathy, i.e., apathy or hyperexcitability, incoordination, aggressiveness, diarrhea, and, usually after 24-96 h, rectal prolapse (BARROS et al., 2007).

Poisoning by PA is a major cause of death of farm animals in Brazil, particularly, of cattle in Rio Grande do Sul, Brazil, and horses in Paraiba, Brazil (LUCENA et al., 2010). However, with the exception of chronic poisoning in sheep, in other species that are affected by acute or chronic PA poisoning photosensitization is uncommon (BARROS et al., 2007). In cattle, photosensitivity can occur only in animals with longer clinical manifestation periods (GIARETTA et al., 2014). This is because when the liver damage is multifocal, photosensitivity tends to be less likely, because there are still healthy hepatocytes removing the phylloerythrin; unlike when the liver damage is diffuse (RADOSTITS et al., 2007). Clinical signs of photosensitivity caused by PA include photophobia, excessive tearing, and serous or mucopurulent eye and nasal discharge. The skin appears edematous and erythematous progressing within 15 to 30 days to necrosis and scabbing (GIARETTA et al., 2014).

Histologically, in cows with photosensitization caused by $S$. brasiliensis poisoning, there is the derangement of liver architecture with an abundant presence of connective tissue and fibroblasts, megalocytosis, and vacuolated hepatocytes. Marked bile duct proliferation is also observed (GIARETTA et al., 2014).

Furans sesquiterpenes (FST) The FST are common toxic compounds in plants. This group includes ngaiona and miodesmona, essential oils that are present in Lasiospermum bipinnatum and in the leaves and fruits of Myoporum spp. Myoporum species that cause liver damage in ruminants include $M$. laetum, $M$. deserti, $M$. tetrandrum, and M. tetrandrum affin (RADOSTITS et al., 2007).

In sheep and cattle, FST poisoning causes photosensitization, jaundice, rumen stasis, constipation, and occasionally tenesmus. 
Photosensitization is characterized by eye and nasal discharge, edema in the ears and face, itching, and severe dermatitis with skin necrosis and crusts. At necropsy, there is severe jaundice and the liver is yellow and enlarged. The gallbladder is distended with an edematous wall. The main histological lesions are periportal or centrilobular necrosis (RAPOSO et al., 2003) and tubular nephrosis (TOKARNIA et al., 1999a). Raposo et al. (2003) reported that cattle have lower sensitivity to the effects of M. laetum than sheep, which may be due to different hepatic metabolism of the hepatotoxic intermediate metabolites in these species. It is noteworthy that the various species and varieties of Myoporum spp. have variable concentrations of toxic and non-toxic compounds and, therefore, variations may occur in plant toxicity in the same region (RAPOSO et al., 2004).

Triterpenes Triterpenic acids are present in Lantana spp. They are rapidly absorbed in the gastrointestinal tract, and, after absorption, they are transformed into active metabolites in the liver, which cause intrahepatic cholestasis by inhibiting bile secretion. The main consequences of cholestasis are photosensitivity, jaundice, and ruminal stasis. The ruminal stasis is marked in Lantana spp. poisoning and is probably due to the decrease in the hepato-ruminal reflex (CHEEKE, 1998). It must be emphasized, however, that plants of this genus are unpalatable and are generally only consumed by naive animals after being transported to areas that have an abundant supply of the plant. Sheep have similar susceptibility to the poisoning as cattle (BRITO et al., 2004); however, the taurine cattle are more susceptible than the zebu cattle (RADOSTITS et al., 2007). In Brazil, there are reports of poisoning of cattle and sheep by L. camara, L. tiliaefolia, and L. glutinosa (RIET-CORREA et al., 1984; TOKARNIA et al., 1999a; BRITO et al., 2004). The characteristic clinical signs of poisoning by Lantana spp. include severe jaundice, dehydration, ruminal stasis, and photosensitivity. Photodermatitis is characterized by hyperemia, edema, and exudation, followed by crust formation. Animals may show nervous signs, including obtundation, circling, ataxia, and aggressiveness (RIVERO et al., 2011). The main microscopic lesions are bile stasis, degeneration of periportal hepatocytes, and nephrosis (BRITO et al., 2004).

Steroidal saponins Steroidal saponins are steroidal glycosides glycosylated by varying numbers of sugar units and are divided into two main structural classes: spirostanol and furostanol saponins (SANTOS et al., 2008). The plants containing steroidal saponins include Brachiaria spp., Panicum spp., Tribulus terrestris, Agave lechuguilla, and Narthecium ossifragum (RIETCORREA et al., 2009).

Initially, photosensitization caused by $B$. decumbens, in Mato Grosso do Sul, was attributed to the saprophytic fungus Pithomyces chartarum (DÖBEREINER et al., 1976), which produces the hepatotoxic mycotoxin named sporidesmin (DI MENNA et al., 1990). However, in Brazil, $P$. chartarum isolated from Brachiaria pastures causing photosensitization did not produce sporidesmin (MEAGHER et al., 1996). Furthermore, outbreaks of photosensitization by Brachiaria spp. in Brazil occurred even with low number of $P$. chartarum spore counts. The presence of steroidal saponins in the chemical composition of Brachiaria was identified as the causal agent of liver injury caused by Brachiaria spp. in Brazil (BRUM et al., 2007).

Saponins are produced by secondary metabolism of plants and have a protection function. Several factors, including stress situations, such as infections by bacteria and fungi, increased temperature, and insolation, may influence saponin concentration and hence the occurrence of outbreaks of photosensitization (BRUM et al., 2009; OLIVEIRA et al., 2013). The stage of growth of the plant is also important; in most cases, saponin concentrations are higher in growing plants, but outbreaks occur throughout the year, probably due to an unexplained rise in saponin concentrations in the plant (RIETCORREA et al., 2011c). There are differences in susceptibility between species, with sheep more susceptible than cattle and young animals more 
susceptible than adults. In Brazil, among ruminants, poisoning by Brachiaria spp. have been reported in cattle, sheep, goats, and buffalo (TOKARNIA et al., 2012; OLIVEIRA et al., 2013). The saponins contained in Brachiaria spp. and Panicum spp. are dicotomin, protodioscin, and saponin B. The hydrolysis of the saponins results in diosgenin and yamogenin sapogenins that, after being metabolized in the digestive tract, produce espismilagenin and episarsasapogenin sapogenins. These sapogenins conjugate with glucuronic acid forming glucuronides, which bind with calcium ions to form insoluble salts that are deposited in the form of crystals (MEAGHER et al., 1996; RIET-CORREA et al., 2011c). The crystals cause inflammation and obstruction of the biliary system, and necrosis of periportal hepatocytes. The crystalloid material can cause photosensitivity and jaundice by physical blockage of the bile flow (TOKARNIA et al., 2012).

The skin lesions initiated with erythema, edema, and pain, are followed by skin necrosis and crust formation. Keratoconjuntivitis with eye discharge is also observed. Various degrees of jaundice, bilirubinemia, and bilirubinuria occur (TOKARNIA et al., 2012). The kidneys can be darkened and the urine may be a dark brown color. Histologically, foamy macrophages, sometimes with crystals, and crystals in the bile ducts are the main liver lesions. Degeneration or necrosis of the periportal hepatocytes, proliferation of bile duct cells, biliary stasis, cholangitis, and periportal fibrosis are also observed (RIET-CORREA et al., 2009).

Plants with unknown toxic compounds that cause secondary photosensitivity

Stryphnodendron spp. The toxic compound of this plant that is responsible for photosensitization is unknown. Yokosuka et al. (2008) isolated triterpenes glycosides from $S$. fissuratum, suggesting that they may be responsible for the photosensitivity. However, these compounds have not been studied experimentally to demonstrate their potential toxicity.
Clinical signs reported in poisoning by Stryphnodendron spp. are anorexia, depression, photophobia, jaundice, abortion, dried feces, edema of the neck, and submandibular and exudative dermatitis (TOKARNIA et al., 2012). Among the species of this genus, $S$. coriaceum, S. obovatum, and $S$. fissuratum are reported in Brazil, and cause photosensitization and lesions of the digestive tract and liver in cattle (TOKARNIA et al., 1991, 1998). Tokarnia et al. (1998) also reported abortions in cows and Albuquerque et al. (2011) induced abortions in goats through ingestion of S. fissuratum pods. Ferreira et al. (2009) failed to reproduce photosensitivity by the administration of S. fissuratum pods in cattle, suggesting that the failure was due to lack of exposure to the sun and to the lesser degree of liver injury observed in the experimental cattle compared to the liver injury observed in the spontaneous intoxication.

Enterolobium spp. Mimaki et al. (2003) reported that E. contortisiliquum pods have six triterpene saponins bisdesmosides described as contortisiliosides A, B, C, D, E, and G. Two of these compounds (A and $C$ ) showed cytotoxic activity in vitro. However, reproduction of the clinicopathological picture of the poisoning with these compounds has not yet been performed. Among the species of this genus, only two are described as causing photosensitivity in Brazil: $E$. contortisiliquum (syn. E. timbouva) (TOKARNIA et al., 1999b) and E. gummiferum (DEUTSCH et al., 1965). Clinical signs of spontaneous poisoning from Enterolobium spp. are photosensitivity and abortion (TOKARNIA et al., 1999b). However, Tokarnia et al. (1999b) in an experimental reproduction with $E$. contortisiliquum in pregnant cows reported anorexia, depression, and diarrhea, but no photosensitivity or abortion. Photosensitivity was observed in the calves and adult cattle that survived to acute digestive signs induced by the administration of pods of E. contortisiliquum (DEUTSCH et al., 1965; LEMOS et al., 1998) and E. gummiferum (DEUTSCH et al., 1965). 


\section{Diagnosis}

The occurrence of photosensitization in pastures containing plants known to cause this syndrome may suggest the diagnosis (Table 1). However, having such information does not scientifically prove the diagnosis and does not distinguish between primary and secondary photosensitization.

The clinical signs of primary and secondary photosensitivity are similar and this may complicate the interpretation and confirmation of the diagnosis by field veterinarians. In ruminants, secondary photosensitivity is more common than primary, and, in general, the secondary type is more severe due to concomitant liver disease (RADOSTITS et al., 2007). Thus, complementary methods for accurate diagnosis are necessary (SANTOS et al., 2008). Blood biochemical tests represent a valuable support to the diagnosis of liver diseases. However, it is important to note that the liver specific enzymes differ among animal species. In adult ruminants, the most useful enzymes in liver disease identification are gamma-glutamyl transferase (GGT), alkaline phosphatase (ALP), sorbitol dehydrogenase (SDH), and aspartate aminotranferase (AST). Results and interpretation of such tests depend on the nature of the lesion and the duration and intensity of the disease (RADOSTITS et al., 2007).

Table 1. Plants causing photosensitization in ruminants in Brazil.

\begin{tabular}{|c|c|c|c|c|c|}
\hline Plant & Family & Common name & Toxic compound & Species affected & References \\
\hline $\begin{array}{c}\text { Brachiaria decumbens } * * \\
\text { B. humidicola } * * \\
\text { B. brizantha** }\end{array}$ & Poaceae & $\begin{array}{l}\text { Capim } \\
\text { braquiária }\end{array}$ & $\begin{array}{l}\text { Steroidal } \\
\text { saponins }\end{array}$ & $\begin{array}{l}\text { Cattle, sheep, } \\
\text { goats, buffalo, } \\
\text { and horses }\end{array}$ & $\begin{array}{l}\text { Tokarnia et al. } \\
\text { (2012); Oliveira et } \\
\text { al. }(2013)\end{array}$ \\
\hline Panicum dichotomiflorum ** & Poaceae & $\begin{array}{l}\text { Capim do } \\
\text { banhado }\end{array}$ & $\begin{array}{l}\text { Steroidal } \\
\text { saponins }\end{array}$ & Sheep & $\begin{array}{l}\text { Riet-Correa et al. } \\
\qquad(2009)\end{array}$ \\
\hline $\begin{array}{l}\text { Lantana camara** } \\
\text { L. tiliaefolia } * * \\
\text { L. glutinosa** }\end{array}$ & Verbenaceae & $\begin{array}{l}\text { Câmara, } \\
\text { cambará, } \\
\text { chumbinho }\end{array}$ & Triterpenes & Sheep and cattle & $\begin{array}{c}\text { Tokarnia et al. } \\
\text { (1999a); Brito et al. } \\
\text { (2004) }\end{array}$ \\
\hline Myoporum laetum $* *$ & Myoporaceae & $\begin{array}{l}\text { Transparente, } \\
\text { cerca-viva }\end{array}$ & $\begin{array}{c}\text { Furans } \\
\text { sesquiterpenes }\end{array}$ & Sheep and cattle & $\begin{array}{c}\text { Raposo et al. (2003, } \\
\text { 2004) }\end{array}$ \\
\hline Senecio brasiliensis** & $\begin{array}{c}\text { Asteraceae } \\
\text { (Compositae) }\end{array}$ & $\begin{array}{l}\text { Flor-das-almas, } \\
\text { tasneirinha, } \\
\text { Maria-mole }\end{array}$ & $\begin{array}{l}\text { Pyrrolizidine } \\
\text { alkaloids }\end{array}$ & $\begin{array}{c}\text { Sheep, cattle and } \\
\text { horses }\end{array}$ & Giaretta et al. (2014) \\
\hline Ammi majus* & Apiaceae & $\begin{array}{l}\text { Âmio-maior, } \\
\text { salsa-de-burro }\end{array}$ & Furocoumarins & Cattle & Méndez et al. (1991) \\
\hline Froelichia humboldtiana* & Amaranthaceae & Ervanço & Unknown & $\begin{array}{c}\text { Sheep, cattle and } \\
\text { Equidae }\end{array}$ & $\begin{array}{l}\text { Pimentel et al. } \\
\text { (2007); Souza et al. } \\
\text { (2012); Knupp et al. } \\
\text { (2014) }\end{array}$ \\
\hline $\begin{array}{c}\text { Stryphnodendron coriaceum } * * \\
\text { S. obovatum } * * \\
\text { S. fissuratum } * *\end{array}$ & Mimosoideae & $\begin{array}{l}\text { Barbatimão, } \\
\text { barbatimão do } \\
\text { nordeste }\end{array}$ & Unknown & Cattle and goats & $\begin{array}{l}\text { Tokarnia et al. } \\
\text { (1991, 1998); } \\
\text { Albuquerque et al. } \\
\text { (2011) } \\
\text { Ferreira et al. } \\
\text { (2009); }\end{array}$ \\
\hline $\begin{array}{c}\text { Enterolobium gummiferum } * * \\
\text { E. contortisiliquum } * * \\
\text { E. timbouva** }\end{array}$ & Mimosoideae & $\begin{array}{l}\text { Tamboril do } \\
\text { campo, orelha } \\
\text { de onça, orelha } \\
\text { de macaco, } \\
\text { timbaúva, timbó }\end{array}$ & Unknown & Cattle and sheep & $\begin{array}{l}\text { Deutsch et al. } \\
\text { (1965); Tokarnia et } \\
\text { al. (1999b) }\end{array}$ \\
\hline
\end{tabular}

*Primary photosensitization

**Secondary photosensitization. 
GGT is present in the cell membrane and located primarily in bile ducts and canaliculi. Its activity is high in the kidney and liver, but only the GGT that originates in the liver is found in plasma. Its activity increases in cholestatic diseases (FRANCISCATO et al., 2006). ALP is distributed widely in the body so that this enzyme alone is not specific to any organ. In liver disorders, ALP serum activity is increased, but not all liver diseases cause significant increase in this enzyme. In addition, AST that is found in high concentrations in the liver is not specific to the diagnosis of liver diseases (RADOSTITS et al., 2007). SDH is the most sensitive and specific enzyme in the early stages of liver disease. In the later stages, the determination of serum bilirubin (BIL) is more appropriate. In the blood serum, BIL is presented in two ways: direct and indirect. The aggregate is the total BIL. Hepatic or biliary diseases cause an increase in the total BIL and direct BIL, and indirect BIL can be increased in cases of acute and diffuse injury of hepatocytes (KANEKO et al., 2008). None of these tests is indicated for liver evaluation of calves under six months old. In such cases, liver biopsies are necessary (RADOSTITS et al., 2007). It must be noted that in the case of primary photosensitization, there is no liver disease and biochemical values are within the normal range. In primary photosensitization, the photodynamic molecules are pre-formed in the toxic plants (RADOSTITS et al., 2007).

Few plant compounds that cause primary photosensitivity have been clearly identified, due to the complex nature of this syndrome and the difficulty of confirming the specific mechanism of action of the compounds and their bioactive metabolites in animal tissues (QUINN et al., 2014). The use of gas chromatography and liquid chromatography coupled with mass spectrometry has improved the possibilities of identifying bioactive photosensitizing compounds in plants as well as in serum, urine, and the skin of animals (WESTON; MATHESIUS, 2013). However, this reality is still far from the veterinary field in Brazil.
Thus, the diagnosis of primary photosensitization should be performed based on the epidemiology, clinical signs, serum biochemical profile, and biopsy of the skin or liver, which helps to exclude lesions caused by other etiologies (KNUPP et al., 2014).

\section{Treatment}

Specific antidotes against the toxic components of the photosensitizing plants are not reported in the literature. However, symptomatic treatment is recommended, including the administration of fluid and vitamin complexes (CHOUDHARY et al., 2013). In addition, the grazing animals must be removed from the paddocks invaded by the plants causing photosensitization and transferred to a place with no sunlight (PIMENTEL et al., 2007; SOUZA et al., 2012). Topical treatment with antibiotics and repellents should also be recommended to avoid secondary contamination and myiasis (RIETCORREA et al., 2007).

\section{Prevention and control of poisoning by photosensitizing plants}

Among the measures recommended to prevent photosensitization caused by plants is to avoid the introduction of animals into pastures severely invaded by these plants (SOUZA et al., 2012). We can also prevent the poisoning by knowing that the toxicity can vary between plant species or varieties, and the susceptibility varies between animal species or in different age groups. It is necessary to know some important factors that may determine the occurrence of poisoning, including palatability, social facilitation, hunger, thirst, transportation, and lack of knowledge of the plant by the animals (PESSOA et al., 2013). Palatability is an important factor in food selection by the ruminants and the production of substances that reduce the palatability is a plant defense mechanism (CHEEKE, 1998). However, this mechanism can be superimposed by social facilitation. Animals that did not consume a 
certain unpalatable plant can start to eat it if they are introduced into a herd with animals that are habituated to eat the plant (RIET-CORREA et al., 2011b). Hunger and thirst also reduce animal selection capability inducing the consumption of plants that were previously not consumed. Some plants are not ingested by animals with previous experience, even under extreme hunger situations, but may be consumed by naive animals after being introduced in the pastures (ALMEIDA et al., 2013).

Other preventive measures include (1) preventing excessive grazing and, if possible, choosing animal species or ages that are resistant to certain plants; (2) after transportation, avoiding grazing in pastures contaminated by toxic plants or the introduction of hungry or thirsty animals into such pastures; (3) isolating the areas invaded by poisonous plants; (4) eliminating toxic species; (5) using controlled seeds to prevent the introduction of toxic plants into pastures; (6) avoiding contamination of hay and silage; and (7) avoiding food shortages during the dry periods by providing fodder reserves (RIETCORREA et al., 2007; TOKARNIA et al., 2012). However, in Brazil, these measures have brought limited results, and other techniques for controlling the poisonings have been studied. In the case of Brachiaria, it is known that $B$. decumbens is the most toxic species; $B$. brizantha and B. ruziziensis are less toxic, whereas $B$. humidicola rarely causes photosensitization in ruminants (BARBOSAFERREIRA et al., 2011). Thus, in the long term, the two most effective measures to control Brachiaria poisoning are the use of species and varieties with low saponin content and grazing resistant animals (PESSOA et al., 2013). It is important to note that cattle are more resistant than are sheep to Brachiaria poisoning and young animals are more susceptible than are adults. There is also different susceptibility in animals of the same herd and it has been demonstrated that, at least among buffalo and sheep, there are also resilient animals (CASTRO et al., 2011; OLIVEIRA et al., 2013).
Regarding prevention of poisoning by pyrrolizidine alkaloids, sheep have low susceptibility to chronic effects, and grazing this species in areas invaded by Senecio spp. has been the best practice to control the plant (BANDARRA et al., 2012). Sheep can also be used to control Crotalaria spp. poisoning, because the ingestion of non-toxic doses induces strong resistance to the poisoning in this species (RIET-CORREA et al., 2011a). Moreover, it is possible to carry out biological control of plants by using insects or other plant pathogens. In Brazil, it was shown that Phaedon confinis, which has specificity for Senecio brasiliensis, might be used, in the future, for the control of this species (MILLÉO et al., 2010).

\section{Final Considerations}

This study reports the main plants that cause photosensitivity in ruminants in Brazil, as well as their toxic principles and mechanisms of action, clinical signs, pathology, and diagnostic methods of the poisonings, and methods of control and prevention. In regard to poisoning by plants with unknown toxic compounds, knowledge of the toxic compounds, their secondary metabolism, and mechanisms of action are necessary to develop techniques for the control and prevention of photosensitivity.

\section{Acknowledgments}

This study was supported by CAPES (Coordenação de Aperfeiçoamento Pessoal de Nível Superior, Brasil) through scholarship Program Doctorate Sandwich Abroad (Proc. N. 8418/2014), and funded by the National Institute of Science and Technology (INCT) for the Control of Plant Poisoning (CNPq Proc. 573534/2008-0). 


\section{References}

ABU-MUSTAFA, E. A.; EL-BAY, F. K. A.; FAYEZ, M. B. E. Ammirin, a new cumarin constituent from Ammi majus L. fruits. Naturwissenschaften, Wuppertal, v. 62, n. 1, p. 39-40, 1975.

ALBUQUERQUE, R. F.; EVÊNCIO-NETO, J.; FREITAS, S. H.; DÓRIA, R. G. S.; SAURINI, N. O.; COLODEL, E. M.; RIET-CORREA, F.; MENDONÇA, F. S. Abortion in goats after experimental administration of Stryphnodendron fissuratum (Mimosoideae). Toxicon, Oxford, v. 58, n. 6-7, p. 602-605, 2011.

ALMEIDA, M. B.; SCHILD, A. L.; PFISTER, J. A.; BRASIL, N. A.; PIMENTEL, M.; FORSTER, K. M.; RIET-CORREA, F. Methods of inducing conditioned food aversion to Baccharis coridifolia (mio-mio) in cattle. Ciência Rural, Santa Maria, v. 43, n. 10, p. 18661871, 2013.

ANDREWS, A. H.; BLOWEY, R. W.; BOYD, H.; EDDY, R. G. Photosensitization. Bovine medicine diseases and husbandary of cattle. $2^{\text {th }}$ ed. Oxford: Blackwell Science, 2004. $1193 \mathrm{p}$.

BANDARRA, P. M.; OLIVEIRA, L. G.; DALTO, A. G.; BOABAID, F. M.; JUFFO, G.; RIET-CORREA, F.; DRIEMEIER, D.; CRUZ, C. E. F. Sheep production as a Senecio spp. control tool. Pesquisa Veterinária Brasileira, Seropédica, v. 32, n. 10, p. 1017-1022, 2012.

BARBOSA-FERREIRA, M. B.; BRUM, K. B.; OLIVEIRA, N. M. R.; VALLE, C. B.; FERREIRA, V. B. N.; GARCEZ, V.; RIET-CORREA, F.; LEMOS R. A. A. Concentração da saponina esteroidal protodioscina em diferentes espécies e cultivares de Brachiaria spp. Veterinária \& Zootecnia, Botucatu, v. 18, p. 580-583, 2011. Suplemento 3.

BARROS, C. S. L.; CASTILHOS, L. M. L.; RISSI, D. R.; KOMMERS, G. D.; RECH, R. R. Biópsia hepática no diagnóstico da intoxicação por Senecio brasiliensis (Asteraceae) em bovinos. Pesquisa Veterinária Brasileira, Seropédica, v. 27, n. 1, p. 53-60, 2007.

BRITO, M. F.; TOKARNIA, C. H.; DÖBEREINER, J. A toxidez das diversas lantanas para bovinos e ovinos no Brasil. Pesquisa Veterinária Brasileira, Seropédica, v. 24, n. 3, p. 153-159, 2004.

BRUM, K. B.; HARAGUCHI, M.; GARUTTI, M. B.; NÓBREGA, F. N.; ROSA, B.; FIORAVANTI, M. C. S. Steroidal saponin concentrations in Brachiaria decumbens and $B$. brizantha at different developmental stages. Ciência Rural, Santa Maria, v. 39, n. 1, p. 279281, 2009.
BRUM, K. B.; HARAGUCHI, M.; LEMOS, R. A. A.; RIET-CORREA, F.; FIORAVANTI, M. C. S. Crystalassociated cholangiopathy in sheep grazing Brachiaria decumbens containing the saponin protodioscin. Pesquisa Veterinária Brasileira, Seropédica, v. 27, n. 1, p. 39-42, 2007.

CASTRO, M. B.; SANTOS JÚNIOR, H. L.; MUSTAFA, V. S.; GRACINDO, C. V.; MOSCARDINI, A. C. R.; LOUVANDINI, H.; PALUDO, G. R.; BORGES, J. R. J.; HARAGUCHI, M.; FERREIRA, M. B.; RIETCORREA, F. Brachiaria spp. poisoning in sheep in Brazil: experimental and epidemiological findings, In: RIET-CORREA, F.; PFISTER, J.; SCHILD, A. L.; WIERENGA, T. (Ed.). Poisoning by plants, mycotoxins and related toxins. Willingford: CAB International, 2011. p. 110-117.

CHEEKE, P. R. Natural toxicants in feeds, forages, and poisonous plants. $2^{\text {th }}$ ed. Danville: Interstate Publishers, 1998. $479 \mathrm{p}$.

CHOUDHARY, G. K.; CHOUDHARY, P. K.; PRASAD, R. Clinical management of photosensitization in a buffalo. Intas Polivet, Gujarat, v. 14, n. 2, p. 225, 2013.

DEUTSCH, J.; DÖBEREINER, J. V.; TOKARNIA, C. H. Fotossensibilidade hepatogênica em bovinos na intoxicação pela fava de Enterolobium gummiferum. In: In: CONGRESSO INTERNACIONAL DE PASTAGENS, 9., 1965, São Paulo. Anais... São Paulo: [s.n.], 1965. p. 1279-1282.

DÖBEREINER, J.; TOKARNIA, C. H.; MONTEIRO, M. C. C.; CRUZ, L. C. H.; PRIMO, A. T. Intoxicação de bovinos e ovinos em pastos de Brachiaria decumbens contaminados por Pithomyces chartarum. Pesquisa Agropecuária Brasileira, Brasília, v. 11, n. 9, p. 87-94, 1976.

EGYED, M. N.; SHLOSBERG, A.; EILAT, A.; MALKINSON, M. Photosensitization in domestic fowl caused by Ammi majus. In: WORLD VETERINARY CONGRESS, 20., Thessaloniki, 1976. Proceedings... Thessaloniki, v. 3, 1976. p. 2353-2354.

FERREIRA, E. V.; BOABAID, F. M.; ARRUDA, L. P.; LEMOS, R. A. A.; SOUZA, M. A.; NAKAZATO, L.; COLODEL, E. M. Intoxicação por Stryphnodendron fissuratum (Mimosoideae) em bovinos. Pesquisa Veterinária Brasileira, Seropédica, v. 29, n. 11, p. 951957, 2009.

FRANCISCATO, C.; LOPES, S. T. A.; VEIGA, A. P. M.; MARTINS, D. B.; EMANUELLI, M. P.; OLIVEIRA, L. S. S. Atividade sérica das enzimas AST, CK e GGT em cavalos Crioulos. Pesquisa Agropecuária Brasileira, Brasília, v. 41, n. 10, p. 1561-1565, 2006. 
GIARETTA, P. R.; PANZIERA, W.; GALIZA, G. J. A.; BRUM, J. S.; BIANCHI, R. M.; HAMMERSCHMITT, M. E.; BAZZI, T.; BARROS, C. S. L. Seneciosis in cattle associated with photosensitization. Pesquisa Veterinária Brasileira, Seropédica, v. 34, n. 5, p. 427-432, 2014.

HAARGIS, A. M.; GINN, P. E. The integument. In: MCGAVIN, M. M.; ZACHARY, J. F. (Ed.). Pathologic basis of veterinary disease. $4^{\text {th }}$ ed. St.Louis: Mosby, Elsevier, 2007. p. 1107-1261

KANEKO, J. J.; HARVEY, J. W.; BRUSS, M. L. Clinical biochemistry of domestic animals. $6^{\text {th }}$ ed. Burlington: Elsevier, 2008. 916 p.

KITAMURA, N.; KOHATANI, S.; NAKAGAKI, R. Molecular aspects of furocoumarin reactions: photophysics, photochemistry, photobiology, and strural analysis. Journal of Photochemistry and Photobiology C, Hiroshi Irie, v. 6, n. 2-3, p. 168-185, 2005.

KNUPP, S. N. R.; BORBUREMA, C. C.; OLIVEIRA NETO, T. S.; MEDEIROS, R.; KNUPP, L. S.; RIET-CORREA, F.; LUCENA, R. B. Surtos de fotossensibilização primária em equídeos causados por Froelichia humboldtiana. Pesquisa Veterinária Brasileira, Seropédica, v. 34, n. 12, p. 1191-1195, 2014.

LEMOS, R.A.; PURISCO, L.; NAKAZATO, L.; DUTRA, I. S. Intoxicação por Enterolobium contortisiliquum. In: LEMOS, R. A. A. (Ed.). Principais enfermidades de bovinos de corte do Mato Grosso do Sul. Campo Grande: Universidade Federal do Mato Grosso do Sul, 1998. p. 307-312.

LUCENA, R. B.; RISSI, D. R.; MAIA, L. A.; DANTAS, A. F. M.; FLORES, M. A.; NOBRE, V. M. T.; RIETCORREA, F.; BARROS, C. S. L. Intoxicação por alcaloides pirrolizidínicos em ruminantes e equinos no Brasil. Pesquisa Veterinária Brasileira, Seropédica, v. 30, n. 5, p. 447-452, 2010.

MALEKI, M.; YAZDANPANAH, M. J.; HAMIDI, H.; JOKAR, L. Evaluation of PUVA-induced skin side effects in patients referred to the Imam Reza Hospital of Mashhad in 2005-2007. Indian Journal of Dermatology, West Bengal, v. 59, n. 2, p. 209, 2014.

MEAGHER, L. P.; MILES, C. O.; FAGLIARI, J. J. Hepatogenous photosensibilization of ruminants by Brachiaria decumbens and Panicum dichotomiflorum in the absence of sporidesmin: lithogenic saponins may be responsible. Veterinary and Human Toxicology, Manhattan, v. 38, n. 4, p. 271-274, 1996.

MEDEIROS, R. M. T.; BEZERRA, V. K. D.; RIETCORREA, F. Intoxicação experimental por Froelichia humboldtiana em equinos. Ciência Rural, Santa Maria, v. 44, n. 10, p. 1837-1840, 2014.
MÉNDEZ, M. C.; RIET-CORREA, F.; SCHILD, A. L.; FERREIRA, J. L.; PIMENTEL, M. Fotossensibilização em bovinos causada por Ammi majus (Umbelliferae) no Rio Grande do Sul. Pesquisa Veterinária Brasileira, Seropédica, v. 11, n. 1-2, p. 17-19, 1991.

DI MENNA, M. E.; HAWKES, A. D.; GARTHWAITE, L. L. Sporidesmin produced by recent Pithomyces chartarum isolates. Mycotoxic Diseases Group, Annual Report, Ruakura Agricultural Research Centre: Waikato, 1990. p. 3.

MILlÉO, J.; CORRÊA, J. H.; PENA CASTRO, J.; PEDROSA-MACEDO, J. H. Host specificity of Phaedon confinis (Coleoptera: Chrysomelidae) for the biocontrol of Senecio brasiliensis (Asteraceae). Revista Brasileira de Entomologia, Curitiba, v. 4, n. 2, p. 61-66, 2010.

MIMAKI, Y.; HARADA, H.; SAKUMA, C.; HARAGUCHI, M.; YUI, S.; KUDO, T.; YAMAZAKI, M.; SASHIDA, Y. Enterolosaponins A and B, novel triterpene bisdesmosides from Enterolobium contortisiliquum, and evaluation for their macrophageoriented cytotoxic activity. Bioorganic \& Medicinal Chemistry Letters, Oxford, v. 13, n. 4, p. 623-627, 2003.

OLIVEIRA, C. H. S. de; BARBOSA, J. D.; OLIVEIRA, C. M. C.; BASTIANETTO, E.; MELO, M. M.; HARAGUCHI, M.; FREITAS, L. G. L.; SILVA, M. X.; LEITE R. C. Hepatic photosensitization in buffaloes intoxicated by Brachiaria decumbens in Minas Gerais State, Brazil. Toxicon, Oxford, v. 73, n. 1, p. 121-129, 2013.

PESSOA, C. R. M.; MEDEIROS, R. M. T.; RIETCORREA, F. Importância econômica, epidemiologia e controle das intoxicações por plantas no Brasil. Pesquisa Veterinária Brasileira, Seropédica, v. 33, n. 6, p. 752758, 2013.

PIMENTEL, L. A.; RIET-CORREA, F.; GUEDES, K. M.; MACÊDO, J. T. S. A.; MEDEIROS, R. M. T.; DANTAS, A. F. M. Fotossensibilização primária em equídeos e ruminantes no semi-árido causada por Froelichia humboldtiana (Amaranthaceae). Pesquisa Veterinária Brasileira, Seropédica, v. 27, n. 1, p. 23-28, 2007.

QUINN, J. C.; KESSELL, A.; WESTON, L. A. Secondary plant products causing photosensitization in grazing herbivores: their structure, activity and regulation. International Journal of Molecular Sciences, Basel, v. 15, n. 1, p. 1441-1465, 2014.

RADOSTITS, O. M.; GAY, C. C.; HINCHCLIFF, K. W.; CONSTABLE, P. D. Veterinary medicine: a textbook of the diseases of cattle, horses, sheep, pigs, and goats. $10^{\text {th }}$ ed. Philadelphia: W. B. Saunders, 2007. 2065 p. 
RAPOSO, J. B.; DRIEMEIER, D.; BARROS, S. S.; GEVEHR-FERNANDES, C. Evolução das lesões histológicas e ultra-estruturais de ovinos e bovinos intoxicados experimentalmente por Myoporum laetum. Pesquisa Veterinária Brasileira, Seropédica, v. 23, n. 4, p. 149-155, 2003.

RAPOSO, J. B.; GEVEHR-FERNANDES, C.; BAIALARDI, C.; DRIEMEIER, D. Observações clínicas e bioquímicas de ovinos e bovinos intoxicados experimentalmente por Myoporum laetum. Acta Scientiae Veterinariae, Porto Alegre, v. 32, n. 1, p. 9-17, 2004.

RIET-CORREA, B.; CASTRO, M. B.; LEMOS, R. A.; RIET-CORREA, G.; MUSTAFA, V.; RIET-CORREA, F. Brachiaria spp. poisoning of ruminants in Brazil. Pesquisa Veterinária Brasileira, Seropédica, v. 31, n. 3, p. 183-192, 2011c.

RIET-CORREA, F.; BEZERRA, C. W. C.; MEDEIROS, R. M. T. Plantas tóxicas do Nordeste. Santa Maria: Sociedade Vicente Pallotti, 2011b. 82 p.

RIET-CORREA, F.; CARVALHO, K. S.; DANTAS, A. F. M.; MEDEIROS, R. M. T. Spontaneous acute poisoning by Crotalaria retusa in sheep and biological control of this plant with sheep. Toxicon, Oxford, v. 58, n. 6-7, p. 606-609, 2011a.

RIET-CORREA, F.; HARAGUCHI, M.; DANTAS, A. F.; BURAKOVAS, R. G.; YOKOSUKA, A.; MIMAKI, Y.; MEDEIROS, R. M. T.; MATOS, P. F. Sheep poisoning by Panicum dichotomiflorum in northeastern Brazil. Pesquisa Veterinária Brasileira, Seropédica, v. 29, n. 1, p. 94-98, 2009.

RIET-CORREA, F.; MÉNDEZ, M. C.; SCHILD, A. L.; SILVA NETO, S. R. Intoxicacao por Lantana glutinosa, em bovinos no estado de Santa Catarina. Pesquisa Veterinária Brasileira, Seropédica, v. 4, n. 1, p. 147-153, 1984.

RIET-CORREA, F.; SCHILD, A. L.; LEMOS, R. A. A.; BORGES, J. R. J. Doenças de ruminantes e equídeos. 3. ed. Santa Maria: Pallotti, 2007. 722 p.

RIVERO, R.; GIANNEECHINI, E.; MATTO, C.; GIL, J. Lantana camara poisoning in cattle and sheep in Uruguay. Veterinaria, Montevideo, v. 47, n. 181, p. 2934, 2011.

SANTOS, J. C. A.; RIET-CORREA, F.; SIMÕES, S. V. D.; BARROS, C. S. L. Patogênese, sinais clínicos e patologia das doenças causadas por plantas hepatotóxicas em ruminantes e equinos no Brasil. Pesquisa Veterinária Brasileira, Seropédica, v. 28, n. 1, p. 1-14, 2008.

SOUZA, P. E. C.; OLIVEIRA, S. S.; AGUIARFILHO, C. R.; CUNHA, A. L. B.; ALBUQUERQUE, R. F.; EVÊNCIO-NETO, J.; RIET-CORREA, F.;
MENDONÇA, F. S. Primary photosensitization in cattle caused by Froelichia humboldtiana. Research in Veterinary Science, Washington, v. 93, n. 3, p. 13371340, 2012.

STALKER, M. J.; HAYES, M. A. Pyrrolizidine alkaloids. In: MAXIE, M. G. (Ed.). Jubb, Kennedy \& Palmer's pathology of domestic animals. $5^{\text {th }}$ ed. San Diego: Academic Press, 2007. v. 2, p. 373-376.

SUBRAMANIAN, P.; RAJAN, S.; KUMAR, S. Physicochemical profile of Ammi Majus. Ancient Science of Life, Mumbai, v. 16, n. 2, p. $142-147,1996$.

TOKARNIA, C. H.; ARMIÉN, A. G.; BARROS, S. S.; PEIXOTO, P. V.; DÖBEREINER, J. Estudos complementares sobre a toxidez de Lantana camara (Verbenaceae) em bovinos. Pesquisa Veterinária Brasileira, Seropédica, v. 19, n. 3-4, p. 128-132, 1999a.

TOKARNIA, C. H.; BRITO, M. F.; BARBOSA, J. D.; PEIXOTO, P. V.; DÖBEREINER, J. Plantas tóxicas do Brasil para animais de produção. 2. ed. Rio de Janeiro: Editora Helianthus, 2012. 586 p.

TOKARNIA, C. H.; BRITO, M. F.; DRIEMEIER, D.; COSTA, J. B. D.; CAMARGO, A. J. B. Aborto em vacas na intoxicação experimental por pelas favas de Stryphnodendron obovatum (Leg. Mimosoideae) em bovinos. Pesquisa Veterinária Brasileira, Seropédica, v. 18, n. 1, p. 35-38, 1998.

TOKARNIA, C. H.; DÖBEREINER, J.; DUTRA, I. S.; BRITO, I. S.; CHAGAS, B. R.; FRANÇA, T. N.; BRUST, L. A. G. Experiments in cattle with the beans of Enterolobium contortisiliquum and E. timbouva to verify their photosensitizing and abortive properties. Pesquisa Veterinária Brasileira, Seropédica, v. 19, n. 1, p. 39-45, 1999b.

TOKARNIA, C. H.; PEIXOTO, P. V.; GAVA, A.; DÖBEREINER, J. Intoxicação experimental por Stryphnodendron coriaceum (Leg. Mimosoideae) em bovinos. Pesquisa Veterinária Brasileira, Seropédica, v. 11, n. 1-2, p. 25-29, 1991.

WESTON, L. A.; MATHESIUS, U. Flavonoids: their structure, biosynthesis and role in the rhizosphere, including allelopathy. Journal of Chemical Ecology, Dordrecht, v. 39, n. 2, p. 283-297, 2013.

YAGER, J. A.; SCOTT, D. W. The skin and appendages. In: JUBB, K. V. F.; KENNEDY, P. C.; PALMER, N. (Ed.). Pathology of domestic animals. $4^{\text {th }}$ ed. San Diego: Academic Press, 1993. v. 1, p. 531-738.

YOKOSUKA, A.; KAWAKAMI, S.; HARAGUCHI, M.; YOSHIHIRO, M. Stryphnosides A-F, six new triterpene glycosides from the pericarps of Stryphnodendron fissuratum. Tetrahedron, Oxford, v. 64, n. 7, p. 14741481, 2008. 
